The Business of Identity 
Stanford Studies in Jewish History and Gulture

e dite д в Aron Rodrigue and Steven J. Zipperstein 


\section{The Business of Identity}

\section{Jews, Muslims, and Economic Life in Medieval Egypt}

Phillip I. Ackerman-Lieberman 
Stanford University Press

Stanford, California

(C) 2014 by the Board of Trustees of the Leland Stanford Junior University. All rights reserved.

No part of this book may be reproduced or transmitted in any form or by any means, electronic or mechanical, including photocopying and recording, or in any information storage or retrieval system without the prior written permission of Stanford University Press.

Printed in the United States of America on acid-free, archivalquality paper

Library of Congress Cataloging-in-Publication Data

Ackerman-Lieberman, Phillip Isaac, I970- author.

The business of identity : Jews, Muslims, and economic life in medieval Egypt / Phillip I. Ackerman-Lieberman. pages $\mathrm{cm}$-(Stanford studies in Jewish history and culture) Includes bibliographical references and index.

ISBN 978-0-8047-8547-I (cloth : alk. paper)

I. Jewish merchants-Egypt-History-To I500.

2. Partnership (Jewish law)-History-To I500.

3. Commercial law (Jewish law)-History-To I500.

4. Jews-Egypt-Identity-History-To I500. 5. EgyptCommerce-History-To I500. 6. Egypt-Economic conditions-640-I5I7. 7. Cairo Genizah. I. Title. II. Series: Stanford studies in Jewish history and culture. DSI35.E4A29 2013 38I.089'924062-dc23 2013021487

ISBN 978-0-8047-87I6-I (electronic)

Typeset by Miles B. Cohen in I0.5/I4 Galliard 